\title{
The effect of tax training and tax understanding on tax compliance
}

\author{
Fitrini Mansur; Eko Prasetyo*; Aulia Beatrice; Riski Hernando
}

\author{
Department of Accountancy, Faculty of Economics and Business, University of Jambi \\ * To whom correspondence should be addressed. Email: ekoprasetyo@ unja.ac.id
}

\begin{abstract}
This study aims to examine the effect of tax training on MSME taxpayer compliance in the city of Jambi. Then, this study also examines the effect of tax knowledge on the compliance of MSME taxpayers in Jambi City. This study uses a moderating variable of tax sanctions on the relationship between tax training and tax knowledge on taxpayer compliance. The population and sample in this study used compulsory taxation for MSMEs in Jambi City, with the data collected utilizing a questionnaire. The results of this study show that tax training affects SME taxpayer compliance and tax knowledge also affects the compliance of MSME taxpayers, and tax sanctions can moderate the relationship between tax training and tax knowledge on MSME taxpayer compliance in Jambi City.
\end{abstract}

Keywords: Tax compliance, Tax training, Tax understanding, Tax sanction

\section{INTRODUCTION}

The growth of Micro, Small, and Medium Enterprises has a reasonably large population in Indonesia. Around 63 million MSMEs in various fields are spread throughout Indonesia and account for $60 \%$ of MSMEs' contribution to GDP in Indonesia. Especially in the city of Jambi, there has been strong sustainability of MSMEs. In 2018 as many as 21,613 MSMEs were much higher than in 2017, namely 12,686 MSMEs recorded from various business lines (culinary, fashion, automotive, agro, and so on). The form of government support for MSMEs is also tremendous. One of them is through socialization and guidance held by the Cooperative, Small, and Medium Enterprises Office in each region. The government fosters MSMEs so that MSMEs can continue to grow in terms of capital, turnover, the number of businesses, labor, and assets (Baining, 2018). Including in Jambi City, the Department of Koperasi regularly provides guidance and training to MSMEs to continue to grow and generate good profits.

One of the state's financing comes from taxes collected from the public, who are taxpayers. However, in the tax collection process, problems are originating from the taxpayer. One of the problems that are a scourge in Indonesia is tax compliance by taxpayers. The level of tax compliance is still shallow compared to the growth of MSMEs in Indonesia, which is not followed by awareness for MSME actors to be on time in paying taxes (Yusro, 2014). One of the causes of tax non-compliance is the lack of training that focuses on MSME taxpayers, which raises its problems. Limited human resources who understand taxes, and are aware of the importance of paying taxes, are increasingly vulnerable for MSMEs to avoid taxes or not comply with taxes. This tax training is in line with the tax knowledge possessed by the taxpayer. Tax training is a way for taxpayers to gain tax knowledge to have the competence and understanding of taxation properly. When the taxpayer has attended training, 
has sufficient knowledge, it is hoped that the UMKM taxpayers will be more obedient in paying taxes. This is important, considering that UMKM is one of the sectors contributing to a significant income for the State, especially for MSMEs that have marketed their products abroad.

Research on tax compliance has been done a lot (Fahmi \& Linda, 2014), but the influence of tax knowledge still varies about tax compliance. The research results conducted by (Fitria \& Supriyono, 2019) said that knowledge and understanding of tax regulations affect taxpayer compliance. Meanwhile, Handayani's (2012) research gave different results, namely that knowledge and understanding of tax regulations affect the willingness to pay for taxpayers. In addition, research conducted by Tiraada (2013), who examined in Minahasa District, stated that tax sanctions are a factor that has a significant effect on Tax Compliance. These results align with research conducted by (Muliari \& Setiawan, 2011), who examined East Denpasar, namely that tax sanctions affect tax compliance. Meanwhile, Anam, Andini, \& Hartono (2016) have different results: tax sanctions do not directly affect tax compliance.

This research is a research development that has been carried out by (Nagel et al., 2019) on taxpayers in the Netherlands. This research is essential because taxpayers' situations, conditions, and awareness are different for each country (Nagel et al., 2019), especially in Indonesia. Besides that, different tax collection in each country is also a factor that can affect tax compliance. Indonesia adheres to a self-assessment system (Tiraada, 2013) which gives taxpayers the freedom to calculate, deposit and report their tax rights and obligations (Mir'atusholihah, 2015).

This study investigates the effect of tax training, tax understanding, tax penalties on SME taxpayer compliance. This research is unique because there are still few studies that examine tax training, and in analyzing tax sanctions, this study also includes training and understanding of taxes and tax penalties as moderating variables. This analysis is to strengthen the researcher's argument regarding the mutually sustainable factors of Tax Compliance. Based on this, the formulation of the problem in this study is how the effect of tax training, understanding tax on tax compliance? Can tax sanctions moderate this relationship? Meanwhile, the Effect of Tax Training, Tax Understanding on Tax Compliance: Case Study of MSMEs in Jambi with Tax Sanctions as Moderating Variables.

\section{LITERATURE REVIEW}

Theory Of Planned Behavior (TPB) which has been developed by Ajzen (1988), is a development of Theory of Reasoned Action (TRA), which is designed to relate to individual behaviors. In the TPB, a variable not applied to TRA is added, namely perceived behavioral control. Theory of Planned Behavior (TPB states that in addition to attitudes towards subjective behavior and norms, individuals also consider behavioral control they perceive, namely their ability to perform these actions. Attribution is the process of forming an impression. Attribution refers to how people explain the causes of behavior in others or themselves. Attribution is the process by which people conclude the factors that influence the behavior of others. Attribution theory states that when individuals observe a person's behavior, the record tries to determine whether it is caused internally or externally (Robbins, 2001)

\section{Micro small and medium enterprises}

The tax compliance behavior of MSMEs is a complex process. It is related to the independence of MSMEs that do not depend on stocks (investors) and bonds (creditors) and have an extreme dependence on major funders (Asai, 2019) so that MSMEs have strong 
relationships with banks. Then, this complexity is also supported by the presence of insensitivity to tax risk, imperfect internal management systems, lack of standardization of the market environment, and lack of government socialization of applicable regulations (Xu \& Huang, 2017) in this case in Indonesia, Government Regulation No. 23 of the year 2018.

First, insensitivity to tax risk, lack of human resources from the financial department who understand accounting, finance, and taxation comprehensively, causing a lack of awareness of the importance of paying taxes, this is also associated with higher costs if hiring HR licensed to taxation sector (Xu \& Huang, 2017). Second, there is a lack of perfect integration of the internal management system of MSMEs, which is associated with no main HR task that focuses on taxes and tends to ignore financial management at the tax level (Xu \& Huang, 2017). Third, the lack of standardization of the market environment is associated with a lack of standardization of the operating process, agreements with suppliers, vendors, and target markets, which tend to have a lousy atmosphere (Xu \& Huang, 2017). Finally, the lack of government socialization of applicable regulations (Xu \& Huang, 2017) - the change in tax rates for MSMEs from $1 \%$ to $0.5 \%$ causes MSMEs not to be adequately educated, so they tend to ignore and feel heavy to pay taxes.

\section{Tax training}

The provision of tax training to MSME actors is critical. This is because this training can teach the importance of paying taxes, the risk of not paying taxes, how to calculate and withhold taxes (Nagel et al., 2019). Then, in tax training, MSME actors can also practice directly the material taught in training (brevet) with their UMKM. The success of tax training can be supported by company planning that has allocated tax training costs as part of research and development (Nagel et al., 2019).

\section{Tax understanding}

Tax knowledge refers to the process, which is closely related to tax regulations and taxrelated information. High tax awareness regarding their obligations to tax payments is also followed by the ability of taxpayers to understand tax laws and regulations and must have the ability to comply with these regulations (Oladipupo \& Obazee, 2016). Increased awareness and understanding of taxes is also a way for people to accept and trust the government when paying taxes (Oladipupo \& Obazee, 2016).

Oliver (2013) states that a good understanding of taxes by entrepreneurs will give positive suggestions. This suggestion will be well received and well implemented and in terms of fulfilling the taxpayer's obligations. In addition, good knowledge of changes to regulations regarding taxation related to tax rates and types of businesses subject to tax strengthens the importance of taxes for the welfare of society (Mahfud, Arfan, \& Abdullah, 2017). MSME taxpayers must understand this.

\section{Tax sanction}

Tax sanctions are guarantees that a taxpayer must pay due to delays or arrears committed by the taxpayer (Cahyani \& Noviari, 2019). The nature of the tax forces all taxpayers to have consequences for sanctions if they are violated (Mangoting \& Sadjiarto, 2013). There are two types of sanctions imposed if the taxpayer is not compliant with taxes: administrative sanctions and criminal sanctions (Utama, 2013). The higher the Tax Sanctions that the violating Taxpayers will receive, it is expected that the Taxpayers will comply in 
carrying out their obligations in paying taxes to the State (Anam et al., 2016). Coupled with human nature will avoid (in this case, sanctions) circumstances that will harm him (Muliari \& Setiawan, 2011). Therefore, in this case, sanctions are necessary as a basis for the consideration of taxpayers so as not to violate their obligations.

\section{Tax compliance}

Compliance in registering, reporting, calculating, and paying taxes owed and paying outstanding tax arrears is compliance that taxpayers must own. Nevertheless, in general, tax compliance can be explained by two theories: First, Deterrence Theory emphasizes incentives that give suggestions to taxpayers that are influenced by economic motives such as increasing profits and detection probability when faced with tax payments (RiahiBelkaoui, 2004). Based on this theory, increasing tax compliance can be done by increasing penalties for non-compliant taxpayers, resulting in high penalties (Oladipupo \& Obazee, 2016), so it is hoped that it can motivate taxpayers to comply in paying taxes. Second, Psychology Theory puts the position that psychological factors influence taxpayers in fulfilling their tax obligations because this theory focuses on the taxpayer's total and ethics (Riahi-Belkaoui, 2004). This theory suggests that taxpayers must comply with taxes, even though the probability of detection of tax avoidance is low (Riahi-Belkaoui, 2004). This theory emphasizes changes in individual attitudes towards the tax system, one of which is tax education (Oladipupo \& Obazee, 2016). Tax compliance criteria can be characterized by at least three factors (Rahmawati et al., 2015): Timeliness in submitting SPT, income earned by taxpayers, and sanctions that will be received when the taxpayer does not comply.

\section{Hypotheses development}

\section{The influence of tax training on MSME tax compliance}

Research on tax training related to tax compliance is relatively new. The focus of this research update, namely on tax training, has been carried out by Nagel et al. (2019) on entrepreneurs in the Netherlands and has produced results that significantly affect tax compliance. The more intense and sustainable the tax training is given, the more obedient the taxpayer will be in paying his taxes. This research was conducted by (Nagel et al., 2019) using experiments and questionnaires distributed to research participants. Then, our research focuses on MSME entrepreneurs because MSMEs have human resource needs that need training, supported by the ability of MSMEs to contribute significantly to the State GDP. Therefore, this study makes the following hypothesis:

H1: Tax training can improve tax compliance on MSME taxpayers

\section{The influence of tax knowledge on MSME tax compliance}

Increasing knowledge and awareness of taxes is vital for society. When the public is aware of the government's reasons for obliging the public to pay taxes, which is supported by the transparency of the use of the people's tax fund allocation by the government or authorized parties, then tax awareness can be expanded not only for the community itself but also impact on other communities which are strengthened by tax policy. Then Fitria \& Supriyono (2019) state that tax knowledge significantly impacts tax needs to meet tax obligations. Tax knowledge can be significant for MSMEs because MSMEs tend not to have expert human resources regarding taxation (Prajogo \& Widuri, 2013). From the description 
above, a common thread can be drawn, namely the more knowledge or understanding of taxes by the MSME taxpayers, will increase their compliance in paying taxes. Therefore, the researcher made the following hypothesis:

H2: Knowledge of tax can improve tax compliance on MSME taxpayers.

The influence of tax sanctions, tax training and tax knowledge on MSME tax compliance

Tax sanctions that can limit not committing tax violations are a fundamental guarantee (Anam et al., 2016). When a foundation is called a tax sanction, it can lure the UMKM taxpayers into complying with taxation, supported by the understanding of the UMKM taxpayers they get from tax training. The more someone understands, the more trained they are in calculating, depositing, and deducting their taxes, then understanding well the sanctions that will be received if they violate, it will increase their tax compliance. Therefore, the researcher made the following hypothesis:

H3: Training and tax knowledge can improve tax compliance on MSME taxpayers when moderated by tax sanctions.

\section{Research framework}

Based on the development of the above hypothesis, the conceptual model in this study can be described as follows:

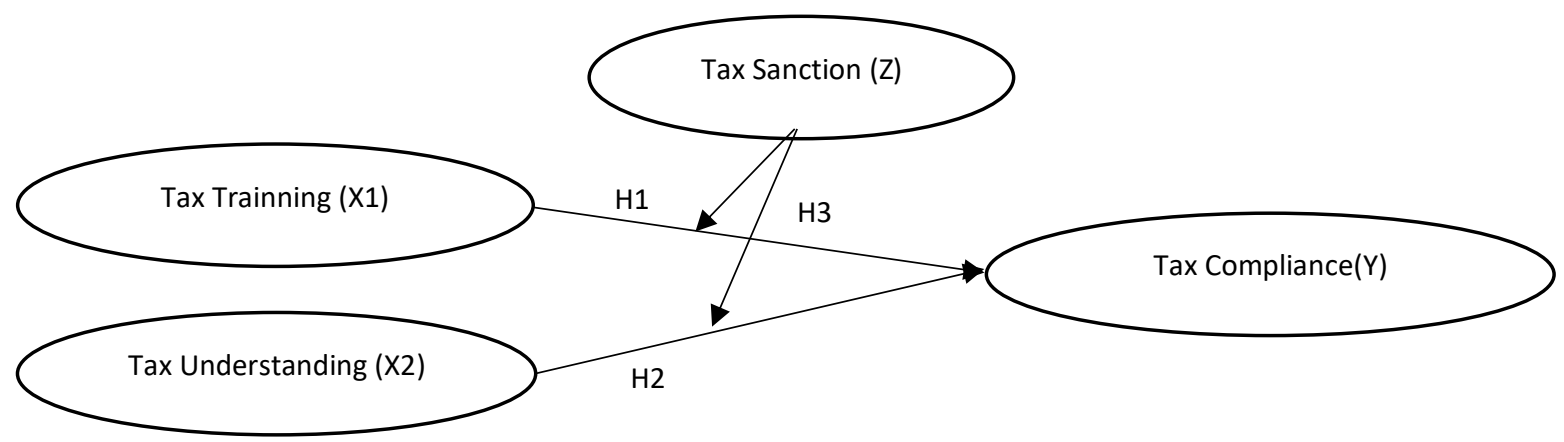

Picture 1: Conceptual model framework

\section{RESEARCH METHOD}

\section{Data sources}

Sources of data in this study using primary data sources and secondary data sources. The primary data source in this study is MSME taxpayers using a questionnaire and using a Likert scale as a measurement scale. Secondary data sources used in this study are obtained through literature, internet media, and data from KPP Pratama Jambi.

\section{Population and sampling}

The population in this study was the UMKM taxpayers in Jambi City. The sampling method was carried out by distributing questionnaires to Jambi City UMKM Taxpayers (as primary data sources) who had attended tax socialization and training (Brevet A and B). 


\section{Research instrument}

The question instrument in this study used a research instrument to measure the variables under study. The number of instruments to be used in this study depends on the number of variables to be studied. Each instrument has a scale, and the scale used in this study is the Likert scale, with the following categories: Strongly Disagree (STS) = 1; Disagree $(\mathrm{TS})=2$; Neutral $(\mathrm{CS})=3$; Agree (4), and Strongly Agree $(\mathrm{ST})=5$.

\section{Instrument validity and reliabilitytest}

The instrument validity test is the accuracy of a research instrument in measuring what you want to measure. This discussion will discuss the item validity testing method. An instrument reliability test is a test to find or determine the consistency of measuring instruments in measuring and whether the instrument used is reliable and consistent if the measurement is carried out repeatedly. The instrument reliability test in this study used Cronbach's alpha method. The alpha method is suitable for scaled scores (e.g., 1-4, 1-5) or range scores (e.g., 0-20, 0-50).

\section{Normality test}

he normality test in the regression model in this study is used to test whether the residual value resulting from the regression usually is distributed or not normally distributed. Meanwhile, a good regression model for this study is a regression model with a residual value that is usually distributed. The normality test method that will be used is the Histogram regression standardized residual and the Normal P-P Plot of regression standardized residual.

\section{Multicollinearity Test}

The multicollinearity test in this study is used to find and determine whether or not there are deviations from the classic multicollinearity assumption, namely that there is a linear relationship between the independent variables in the regression model. Several conditions must be met in the regression model in this study, namely the absence of multicollinearity. Multicollinearity testing in this study will be carried out by looking at the inflation factor (VIF) value on the regression model and also tested by comparing the individual determination coefficient (r2) with the determination value simultaneously (R2). The test criterion is if $\mathrm{r} 2>\mathrm{R} 2$, then multicollinearity occurs, and if $\mathrm{r} 2<\mathrm{R} 2$, there is no multicollinearity.

\section{Heteroscedasticity test}

The heteroscedasticity test in this study is used to find and determine whether or not there are deviations from the classical assumptions of heteroscedasticity. Name is inequality of variants of the residuals for all observations in the regression model in this study. One of the prerequisites that must be met in the regression model is the absence of heteroscedasticity symptoms. The test method used is the Glesjer test.

\section{Data analysis method}

This study uses a quantitative approach because this study uses the measurement of research variables with numbers and performs data analysis with statistical processes. Methods of data analysis in this study using multiple regression analysis models (multiple regression analysis). Multiple regression models aim to predict the dependent variable's size 
by using the independent variable's data whose size is known (Santoso, 2004: 47). This analysis technique is used to determine the effect of the dependent variable (Y), namely taxpayer compliance, while the independent variables consist of Tax Training (X1), Tax Knowledge (X2), and Tax Sanctions (X3) and adding the Tax Rate as a control variable (X4). Thus, the equations that will be used in this study are as follows.

Hypothesis Testing Model 1 and 2

$\mathrm{Y}=\boldsymbol{\beta 1 X 1}+\boldsymbol{\beta 2} \mathrm{X} 2+\beta 4 \mathrm{X} 4+\mathrm{e}$

Hypothesis Testing Model 3

$\mathbf{Y}=\boldsymbol{\beta}_{1} \mathbf{X}_{1}+\boldsymbol{\beta}_{2} \mathbf{X}_{2}+\beta_{3} \mathbf{X}_{3}+\beta_{3} \mathbf{X}_{3} * \mathbf{X}_{1}+\boldsymbol{\beta}_{3} \mathbf{X}_{3} * \mathbf{X}_{2}+\mathrm{e}$

Information:

$\mathrm{Y}=$ Taxpayer compliance

B1 = Taxpayer training regression coefficient

$\beta 2=$ Taxpayer knowledge regression coefficient

$\beta 3=$ Taxpayer sanctions regression coefficient

$\beta 4=$ Tax rate regression coefficient

\section{Hypotheses testing}

\section{Coefficient determination $\mathbf{R}^{2}$}

The coefficient of determination (R2) is used in this study, in essence, to measure how far the model's ability to explain the variation in the dependent variable. If the value of $\mathrm{R} 2$ is small, it means that the ability of the independent variables to explain the variation of the dependent variable is minimal (Ghozali, 2012).

\section{F test}

The $\mathrm{F}$ test uses a significant level of $5 \%$, by comparing the calculated $\mathrm{F}$ value with the $\mathrm{F}$ value according to the table, if the calculated $\mathrm{F}$ value is greater than the $\mathrm{F}$ table value, then the regression model can be used to predict or in other words the model used is fit.

\section{t test}

The t-test is used to determine whether the independent variable $(\mathrm{X} 1, \mathrm{X} 2, \ldots . \mathrm{Xn})$ partially has a significant effect on the dependent variable (Y). The t-test uses a significant level of $5 \%$, by comparing the $t$ statistical value with the critical point according to the table, if the $t$ statistical value is higher than the $t$ table value, we accept an alternative hypothesis which states that an independent variable individually affects the dependent variable.

\section{Result of discussion}

\section{Validity test}

Based on the results of the validity test of the UMKM taxpayer compliance variable (Y), it shows that item $\mathrm{Y} 1$ has a correlation value or $\mathrm{r}$ count of 0.585 , item $\mathrm{Y} 2$ has a correlation value or $r$ count with a value of 0.589 , then item Y3 has a correlation value or $r$ 
count of 0.528 . Then, item Y4 has a correlation value or $r$ count of 0.519 . Respondents of MSME taxpayers in this study amounted to 120 MSME taxpayers where the significance was at a value of 0.05, and the value of $r$ table was 0.195. Based on this, $r$ count items $Y 1$, Y2, Y3, and Y4 have a valuer table. Thus, the taxpayer compliance items (Y) are declared valid.

Based on the results of the item validity test of the Tax Training variable (X1), it can be seen that item X1.1 has a correlation value or $\mathrm{r}$ count 0.744 , item $\mathrm{X} 1.2$ has a correlation value, or $r$ counts 0.708 , item X1.3 has a correlation value, or $r$ counts 0.701 , items X1.4 has a correlation value or $\mathrm{r}$ count 0.585 , and item X1.5 has a correlation value or $\mathrm{r}$ count 0.455 . With the number of respondents 120 , the significance level is 0.05 ; the $\mathrm{r}$ table value is 0.195 . Thus, the tax training items are declared valid because $\mathrm{r}$ count items X1.1, X1.2, X1.3, X1.4, and $\mathrm{X} 1.5 \geq \mathrm{r}$ table.

The test results of the item validity of the Tax Knowledge variable (X2) show that item X2.1 has a correlation value or $\mathrm{r}$ count 0.582 , item X2.2 has a correlation value or $\mathrm{r}$ count 0.589 , item X2.3 has a correlation value or $r$ count 0.547 . With the number of respondents 120 , the significance level is 0.05 . Then the $r$ table value is 0.195 . Thus, because $\mathrm{r}$ count items X2.1, X2.2, X2.3 $\geq \mathrm{r}$ table, the knowledge items are declared valid.

The test results of the item validity of the Tax Sanctions variable (X3) show that item X3.1 has a correlation value or $r$ count 0.465 , item X3.2 has a correlation value or $r$ count 0.390 , item X3.3 has a correlation value or $\mathrm{r}$ count 0.331 , item X3 .4 has a correlation value or $r$ count 0.286 . With the number of respondents 120 , the significance level is 0.05 . Then the $r$ table value is 0.195 . Thus, the sanction items are declared valid because $r$ counts items $\mathrm{X} 3.1, \mathrm{X} 3.2, \mathrm{X} 3.3, \mathrm{X} 3.4 \geq \mathrm{r}$ table.

\section{Reliability Test}

The reliability test used the Alpha (Cronbach's) method. Based on the research results for variable $\mathrm{Y}$ obtained an alpha value of 0.787 and an $r$ table value of 0.195 . So, This means that the taxpayer compliance variable instrument is reliable because $r$ count $\geq r$ table. The tax training variable item (X1) alpha value is 0.814 , and the $r$ table value is 0.195 . This means that the tax training variable instrument is reliable because $r$ count $\geq \mathrm{r}$ table. The tax knowledge variable item (X2) alpha value is 0.783 , and the $r$ table value is 0.195 . This means that the tax knowledge variable instrument is reliable because $r$ count $\geq \mathrm{r}$ table. The alpha value of the tax sanction variable item (X3) is 0.564 , and the $r$ table value is 0.195 . This means that the tax sanction variable instrument is reliable because $r$ count $\geq r$ table. The moderating effect in this study has a Cronbach alpha value of 1,000 with $\mathrm{R}$ Table greater than the $\mathrm{T}$ count value.

Table 1. Reliability test results

\begin{tabular}{lccc}
\hline \multicolumn{1}{c}{ Variabel } & Cronbach Alpha & R table & Keterangan \\
\hline Moderating Effect 1- Tax Sanction & 1,000 & 0,195 & Reliable \\
Moderating Effect 2- Tax Sanction & 1,000 & 0,195 & Reliable \\
Tax Training & 0,814 & 0,195 & Reliable \\
Tax Understanding & 0,783 & 0,195 & Reliable \\
Tax Compliance & 0,787 & 0,195 & Reliable \\
Tax Sanction & 0,564 & 0,195 & Reliable \\
\hline
\end{tabular}

Sources: Data Processed, 2021 


\section{Normality test}

The distribution of data with a residual value (error) displays the normal distribution conditions on the histogram. The Normal P-P Plot graph can be judged from the distribution points around the diagonal line whether it is in the same direction and follows the diagonal line. Normal P - Plot shows the distribution of data following the diagonal line.

\section{Multicolonierity test}

Multicollinearity testing in this study it is obtained that the VIF data is around number 1 and has a tolerance number close to 1 . Thus it can be said that the data is free from multicollinearity. However, to support this analysis, the data of the individual determination coefficient (R2) and the simultaneous determination value (R2) are compared. Based on the test results, it was obtained that the value of the individual determination coefficient (R2) for the training variable for compliance was 0.115 , the training variable for sanctions was 0.143 , the knowledge variable for sanctions was 0.209, the knowledge variable for service was 0.102 , the variable for sanctions on service was 0.055 . The value of $\mathrm{R} 2$ is 0.656 . These results indicate that the value of $\mathrm{r} 2<\mathrm{R} 2$ means that there is no multicollinearity.

\section{Heteroscedasticity test}

The test method used is the Glesjer test. If the significance value between the independent variables and the absolute residual is more than 0.05 , there is no heteroscedasticity problem. Based on the test, the significance value of the independent variable is more than 0.05 , so based on the results of the Glejser test, it is concluded that there is no heteroscedasticity problem.

\section{Multiple linear regression analysis}

The following are the results of multiple linear regression analysis:

Table 2: Multiple linear regression analysis results

\begin{tabular}{|c|c|c|c|c|c|c|}
\hline & \multicolumn{6}{|c|}{$\begin{array}{c}\text { Coefficientsa } \\
\end{array}$} \\
\hline & \multirow[t]{2}{*}{ Model } & \multicolumn{2}{|c|}{$\begin{array}{l}\text { Unstandardized } \\
\text { Coefficients }\end{array}$} & \multirow{2}{*}{$\begin{array}{c}\text { Standardized } \\
\text { Coefficients } \\
\text { Beta }\end{array}$} & \multirow[t]{2}{*}{$\mathbf{t}$} & \multirow[t]{2}{*}{ Sig } \\
\hline & & B & Std Error & & & \\
\hline \multirow[t]{4}{*}{11} & Constant & -7.317 & 1.754 & & -4.252 & 0.000 \\
\hline & Training & 0.421 & 0.027 & 0.472 & 5.678 & 0.000 \\
\hline & Understanding & 0.452 & 0.170 & 0.256 & 3.926 & 0.000 \\
\hline & Sanction & 0.486 & 0.121 & 0.247 & 4.148 & 0.000 \\
\hline
\end{tabular}

a. Dependent variable: Compliance

Sources: Data Processed, 2021 obtained:

Based on the output of the regression results in table 1, the following equation is $Y^{\prime}=\mathrm{a}+\beta 1 \mathrm{X} 1+\beta 2 \mathrm{X} 2+\beta 3 \mathrm{X} 3+\mathrm{e}$
$Y^{\prime}=-7,317+0,421 \mathrm{X} 1+0,452 \mathrm{X} 2+0,486 \mathrm{X} 3+\mathrm{e}$

The value of the constant (a) is -7,317, which means that if tax training, tax knowledge, tax sanctions are 0 (zero), then the compliance of the MSME taxpayer is 
negative, namely $-7,317$. The regression coefficient value of the tax training variable (ß1) is positive, 0.421 , which means that for every increase in the value of tax training is 1 , the individual taxpayer compliance value will also increase by 0.421 . The regression coefficient value of the tax knowledge variable ( $(2)$ is positive, namely 0.452 . This means that for every increase in the value of tax knowledge is 1 , then the compliance value of individual taxpayers will also increase by 0.452 . The regression coefficient value of the tax sanctions variable (B3) is positive. Namely, 0.486 means that for every increase in the value of tax sanctions by 1 , the compliance value of individual taxpayers will also increase by 0.486 .

\section{Hypothesis test}

\section{Coefficient of determination $\left(\mathbf{R}^{2}\right)$}

Based on the regression analysis results, it was obtained $R^{2}$ ( $R$ Square) with a value of 0.656 or $(65.6 \%)$. This means that the percentage of the contribution of the influence of the independent variables (tax training, tax knowledge, tax sanctions) on the dependent variable (MSME taxpayer compliance) is 65.6\%. In contrast, the remaining $34.4 \%$ is influenced or explained by other variables outside of this research model.

Table 3. Coefficient determination

\begin{tabular}{lccc}
\hline No & Model & R Square & Standard Error of the Estimate \\
\hline $\mathbf{1}$ & 1 & 0.656 & 169245.205 \\
\hline
\end{tabular}

Sources: Data Processed, 2021

\section{F test}

Based on the regression analysis output results for tax training, it is obtained that the $\mathrm{F}$ count is 57.107 . Using the $95 \%$ confidence level, $\mathrm{a}=5 \%$, the results for the F table are 2.46 . The test criteria state that Ho is accepted if $\mathrm{F}$ count $\leq \mathrm{F}$ table and Ho is rejected if $\mathrm{F}$ count $>\mathrm{F}$ table. By comparing the F count with the F table (57.107> 2.46), then Ho is rejected. In conclusion, the understanding tax affects the compliance of MSME taxpayers in Jambi City. Then, the results of the regression analysis output for tax knowledge obtained an F count of 46.219. This result is greater than the F table, which is only 2.46 with an accuracy level of $5 \%$. So it can be concluded that tax knowledge affects MSME taxpayer compliance in the city of Jambi.

Table 4. F test results

\begin{tabular}{lccc}
\hline & F Count & F Table & Conclussion \\
\hline Tax Training -> Tax Compliance & 57,107 & 2,46 & Accepted \\
Tax Understanding -> Tax Compliance & 46,129 & 2,46 & Accepted
\end{tabular}

Sources: Data Processed

\section{CONCLUSSION}

Based on the discussion above, it can be concluded that tax training affects MSME taxpayer compliance in Jambi. This result aligns with some previous research that taxpayers who have attended tax training such as brevets and other tax training will influence the taxpayer to comply with their tax obligations. In addition, tax knowledge in this study also 
affects the compliance of MSME taxpayers in Jambi. This result is also in line with several previous research findings that if taxpayers know about taxation, it will affect their compliance as a taxpayer. Finally, tax sanctions in this study as a moderating variable for the relationship between the two variables, tax training, and tax knowledge, affect taxpayers to comply with tax regulations. These results are also in line with previous research findings where tax sanctions can moderate the relationship between training and knowledge of taxpayer compliance.

This study also has limitations, including not all UMKM taxpayers in Jambi sampled in this study. The following limitation comes from the not up-to-date questionnaire instrument. The tax sanctions in this study are only as moderators. If it is used as a mediating variable, it may produce different findings. For further research, you can use MSME taxpayers in different places. Then it can add other independent variables besides tax training and tax knowledge. Then can use a moderating variable other than tax sanctions. Contributions to this research can contribute both theoretically and practically. Further researchers can use the theoretical contribution of this research as a basis or reference. The practical contribution of this research is seen to be used by taxpayers and tax staff.

\section{REFERENCES}

Anam, M. C., \& Andini, R. Hartono.(2018). Pengaruh kesadaran wajib pajak, pelayanan fiskus dan sanksi pajak terhadap kepatuhan wajib pajak orang pribadi yang melakukan kegiatan usaha dan pekerjaan bebas sebagai variabel intervening (studi di KPP pratama salatiga). Journal of Accounting, 4(4), 30-44.

Asai, Y. (2019). Why do small and medium enterprises (SMEs) demand property liability insurance?. Journal of Banking \& Finance, 106, 298-304.

Baining, M. E. (2018). Pelaporan kewajiban perpajakan dilihat dari tingkat pemahaman, tingkat kepatuhan, dan ketegasan sanksi perpajakan pemilik UMKM di Kota Jambi. Imara, Jurnal Riset Ekonomi Islam, 2(1).

Fahluzy, S. F., \& Agustina, L. (2014). Faktor-faktor yang mempengaruhi kepatuhan membayar pajak UMKM di Kabupaten Kendal. Accounting Analysis Journal, 3(3).

Fasmi, L., \& Misra, F. (2014). Modernisasi Sistem Administrasi Perpajakan dan Tingkat Kepatuhan Pengusaha Kena Pajak. Jurnal Akuntansi Multiparadigma, 5(1), 76-87.

Fitria, P. A., \& Supriyono, E. (2019). Pengaruh pemahaman peraturan perpajakan, persepsi tarif pajak, dan keadilan perpajakan terhadap kepatuhan wajib pajak. ECONBANK: Journal of Economics and Banking, 1(1), 47-54.

Lazuardini, E. R., Susyanti, J., \& Priyono, A. A. (2018). Pengaruh pemahaman peraturan perpajakan, tarif pajak dan sanksi pajak terhadap kepatuhan wajib pajak UMKM (studi pada wajib pajak orang pribadi yang terdaftar di KPP Pratama Malang selatan). Jurnal Ilmiah Riset Manajemen, 7(01).

Mahfud, M. A., Mahfud, S. A., Arfan, M., Mahfud, S. A., Arfan, M., \& Abdullah, S. (2017). Pengaruh Pemahaman Peraturan Perpajakan, Kesadaran Membayar Pajak dan Kualitas Pelayanan Perpajakan Terhadap Kepatuhan Wajib Pajak Badan (Studi Empiris pada Koperasi di Kota Banda Aceh). Jurnal Administrasi Akuntansi: Program Pascasarjana Unsyiah, 6(3).

Mangoting, Y., \& Sadjiarto, A. (2013). Pengaruh postur motivasi terhadap kepatuhan wajib pajak orang pribadi. Jurnal Akuntansi dan Keuangan, 15(2), 106-116. 
Mir'atusholihah, M. (2013). Pengaruh Pengetahuan Perpajakan, Kualitas Pelayanan Fiskus dan Tarif Pajak terhadap Kepatuhan Wajib Pajak (Studi pada Wajib Pajak UMKM di Kantor Pelayanan Pajak Pratama Malang Utara). Doctoral dissertation, Brawijaya University: Malang

Muliari, N. K., \& Setiawan, P. E. (2011). Pengaruh persepsi tentang sanksi perpajakan dan Kesadaran wajib pajak pada kepatuhan Pelaporan wajib pajak orang pribadi di kantor Pelayanan pajak pratama denpasar timur. Jurnal Ilmiah Akuntansi dan Bisnis, 6(1).

Nagel, H., Huber, L. R., Van Praag, M., \& Goslinga, S. (2019). The effect of a tax training program on tax compliance and business outcomes of starting entrepreneurs: Evidence from a field experiment. Journal of business venturing, 34(2), 261-283.

Oladipupo, A. O., \& Obazee, U. (2016). Tax knowledge, penalties and tax compliance in small and medium scale enterprises in Nigeria. IBusiness, 8(1), 1-9.

Oliver, J. (2013). 済無 No title no title. Journal of Chemical Information and Modeling, 53(9), 1689-1699.

Prajogo, J. N., \& Widuri, R. (2013). Pengaruh tingkat pemahaman peraturan pajak wajib pajak, kualitas pelayanan petugas pajak, dan persepsi atas sanksi perpajakan terhadap kepatuhan wajib pajak UMKM di Wilayah Sidoarjo. Tax \& Accounting Review, 3(2), 175.

Pertiwi, H. I., Purwanto, (2019). Pengaruh tarif pajak, pemahaman pajak dan sanksi perpajakan terhadap kepatuhan wajib pajak orang pribadi (studi pada wajib pajak orang pribadi bukan pegawai di KPP Pratama Bandung Cibeunying).

Riahi-Belkaoui, A. (2004). Relationship between tax compliance internationally and selected determinants of tax morale. Journal of international accounting, auditing and taxation, 13(2), 135-143.

Tiraada, T. A. (2013). Kesadaran perpajakan, sanksi pajak, sikap fiskus terhadap kepatuhan wpop di kabupaten minahasa selatan. Jurnal EMBA: Jurnal Riset Ekonomi, Manajemen, Bisnis dan Akuntansi, 1(3).

Utama, I., \& Mustika, W. (2013). Pengaruh kualitas pelayanan, sanksi perpajakan dan biaya kepatuhan terhadap kepatuhan wajib pajak. E-Jurnal Fakultas Ekonomi Universitas Udayana (UNUD), Bali, Indonesia, 453.

XU, X. L., \& HUANG, L. J. (2017). Research on tax risk management and control strategy of small and medium enterprise. DEStech transactions on social science, education and human science, (aetms). 167-170, https://doi.org/10.12783/dtssehs/aetms2017/ 15860

Yusro, H. W., \& Kiswanto, K. (2014). Pengaruh tarif pajak, mekanisme pembayaran pajak dan kesadaran membayar pajak terhadap kepatuhan wajib pajak UMKM di Kabupen Jepara.Accounting Analysis Journal, 3(4). 429-436, https://doi.org/10.15294/aaj. v3i4.4201 